\title{
APLIKASI MALTODEKSTRIN PADA PEMBUATAN YOGURT BUBUK BIJI NANGKA (Arthocarpus lineus)
}

\author{
Masyhura MD ${ }^{1}$, Misril Faudi ${ }^{1}$, dan Surnaherman ${ }^{2}$ \\ ${ }^{1}$ Program Studi Teknologi Hasil Pertanian, Fakultas Pertanian, Universitas Muhammadiyah Sumatera Utara \\ ${ }^{2}$ Program Studi Agribisnis, Fakultas Pertanian, Universitas Muhammadiyah Sumatera Utara \\ Email: masyhura@umsu.ac.id
}

\begin{abstract}
ABSTRAK
Penelitian ini bertujuan untuk mengetahui pengaruh konsentrasi maltodekstrin terhadap kadar protein, total mikroba, total asam dan kadar air pada yogurt bubuk dari biji nangka. Metode yang digunakan adalah Rancangan Acak Lengkap non-faktorial dengan konsentrasi maltodekstrin (M) terdiri dari 4 taraf $\left(\mathrm{M}_{1}=10 \%, \mathrm{M}_{2}=15 \% \quad \mathrm{M}_{3}=20 \%, \mathrm{M}_{4}=25 \%\right)$ dan 3 ulangan. Penelitian ini menggunakan analisis secara kuantitatif yaitu kadar protein, total mikroba, total asam dan kadar air. Parameter penelitian ini diolah secara ANOVA dan dilanjutkan uji DMRT 5\% menggunakan software IBM SPSS Statistik. Hasil penelitian menunjukan bahwa penambahan konsentrasi maltodekstrin dari 10-25\% menunjukkan peningkatan kadar protein, total mikroba, dan kadar air, namun menurunkan total asam pada yoghurt bubuk biji nangka dengan konsentrasi terbaik terdapat pada $25 \%$.

Kata kunci— biji nangka; maltodekstrin; yogurt
\end{abstract}

\section{PENDAHULUAN}

Kesadaran masyarakat saat ini akan pentingnya kesehatan semakin meningkat. Salah satunya adalah dengan meningkatnya konsumsi produk-produk pangan fungsional. Salah satu produk pangan fungsional yang sedang berkembang saat ini adalah minuman susu fermentasi yang mengandung probiotik, sekitar $65 \%$ produk pangan fungsional yang beredar saat ini merupakan produk pangan probiotik. Terdapat berbagai jenis produk yang telah dikenal luas mengandung probiotik, sebagian besar diantaranya merupakan produk turunan susu seperti kefir, yoghurt, susu fermentasi 'yakult', keju dengan Bifidus infantis, es krim dengan berbasis susu fermentasi, dan produk susu bubuk yang mengandung bifidus untuk anak-anak (Nurhidayat, 2009).

Yoghurt adalah salah satu pangan fungsional yang diperoleh dari fermentasi susu dengan bantuan bakteri asam laktat (BAL). Yoghurt mempunyai banyak manfaat bagi kesehatan, yaitu mengatur saluran pencernaan, antidiare, antikanker, membantu penderita lactose intolerance dan mengatur kadar kolesterol dalam darah. Yoghurt merupakan produk susu yang mudah dicerna dalam saluran pencernaan dibandingkan dengan susu murni atau whole milk (Askar dan Sugiarto, 2005).

Yoghurt berasal dari susu hewan ternak yang kemudian ditambahkan dengan bakteri asam laktat yang akan membentuk asam laktat. Bakteri yang biasa digunakan dalam proses pembuatan yoghurt adalah bakteri Bifidobacterium sp., Lactobacillus sp., bakteri Streptococcus thermophilus dan Lactobacillus bulgaricus. Bakteri-bakteri ini yang akan memicu proses fermentasi dari susu, mengubah laktosa susu menjadi asam laktat. Efek lain dari proses fermentasi adalah pecahnya protein pada susu yang menyebabkan tekstur susu menjadi kental. Hasil akhirnya susu akan terasa asam dan kental, inilah bentuk yoghurt dasar yang telah jadi (Gustiawati, 2007).

Pembuatan yoghurt dengan rasa manis baik karena ditambah gula maupun ditambah buah lebih disukai oleh konsumen (Hoppert et al., 2013). Azizah et al., (2013) juga melaporkan yoghurt dari ekstrak nangka mengurangi rasa asam dan meningkatkan kesukaan/ketertarikan panelis. namun, pemanfaatan biji nangka sebagai bahan pembuatan yogurt selama ini hanya sedikit pemanfaatannya untuk diversifikasi pangan (MD et al., 2016).

Daya simpan yoghurt biji nangka relatif singkat (tidak tahan lama), pengamatan yang telah dilakukan pada studi pendahuluan menunjukkan penyimpanan yoghurt biji nangka di dalam lemari pendingin hanya bertahan 1 minggu, sehingga yoghurt biji nangka tersebut perlu dibuat menjadi bentuk bubuk untuk memperpanjang daya simpannya (MD dan Surnaherman, 2018).

Pembuatan yoghurt bubuk merupakan salah satu alternatif pengolahan yoghurt dengan pengolahan lebih lanjut dengan membuat produk kering selain itu yoghurt bubuk memiliki kelebihan lain yaitu memiliki umur simpan yang tinggi dan dapat disimpan dalam suhu ruang. Pengeringan 
dapat mengurangi kerusakan bahan pangan dalam jumlah tertentu dan akibat positif dari pengeringan produk baru yang dapat memberikan kemudahan dalam transportasi dan penyimpanan dalam bahan pangan (Baharuddin, 2006). Pembuatan yoghurt bubuk membutuhkan bahan pengisi untuk mencegah terjadinya kerusakan mikroba pada saat proses pengeringan. Bahan pengisi dibutuhkan untuk mempercepat proses pengeringan, meningkatkan rendemen, melapisi komponen, flavor dan mencegah kerusakan akibat panas (Baharuddin, 2006). Menurut Historiya (2017), pada penelitian pengaplikasian maltodekstrin sebagai bahan pengisi dalam pembuatan minuman serbuk instan buah pakel ikut berperan untuk melindungi kualitas antioksidan dalam minuman tersebut. Estiasih dan Sofia, (2009) melaporkan bahwa bahan pengisi yang dipakai berfungsi untuk memperbesar volume bahan dan meningkatkan total padatan bahan terlarut, sehingga rendemen yang dihasilkan akan semakin bertambah jumlahnya. Tujuan penelitian ini mengetahui pengaruh konsentrasi maltodekstrin terhadap kadar protein, total mikroba, total asam dan kadar air pada yogurt bubuk dari biji nangka.

\section{MOTODOLOGI PENELITIAN}

\section{A. Waktu dan Tempat Penelitian}

Analisis kadar protein, total mikroba, total asam dan kadar air dilakukan di Laboratorium Teknologi Hasil Pertanian, Fakultas Pertanian, Universitas Muhammadiyah Sumatera Utara, Medan pada September sampai Oktober 2020.

\section{B. Bahan dan Alat Penelitian}

Bahan penelitian yang digunakan adalah biji nangka, susu skim, starter yogurt, dan maltodekstrin. Peralatan yang digunakan antara lain spektrofotometer UV-Vis, inkubator, oven, repraktometer dan colony counter.

\section{Metode Penelitian}

Metode penelitian menggunakan Rancangan Acak Lengkap non-faktorial dengan konsentrasi maltodekstrin (M) yang terdiri dari 4 taraf yaitu: $\mathrm{M} 1=10 \%, \mathrm{M} 2=15 \%, \mathrm{M} 3=20 \%$, M4 $=25 \%$ dengan 3 ulangan. Parameter penelitian ini diolah secara ANOVA dan dilanjutkan uji DMRT 5\% menggunakan software IBM SPSS Statistik v.20.

\section{Pelaksanaan dan Parameter Penelitian}

Biji nangka dipisahkan dari daging buahnya lalu dicuci kemudian direndam selama 12 jam dan direbus didalam $500 \mathrm{ml}$ air. Setelah 15 menit, biji nangka diangkat dan ditiriskan. Setelah dingin, kulit biji nangka dipisahkan dari bijinya dan dipotong ukuran kecil. Potongan biji nangka diblender dengan ditambahkan air dengan perbandingan 1:4. Diblender selama 3 menit atau sampai biji nangka halus. Susu biji nangka disaring. Setelah disaring susu biji nangka direbus. Dimasak dengan suhu $85^{\circ} \mathrm{C}$ sambil diaduk terus selama 2 menit tetapi jangan sampai mendidih kemudian tambahkan $8 \%$ susu skim. Jika sudah, solid yogurt lalu diangkat dan didinginkan kira-kira sampai hangat hangat kuku (40$44^{\circ} \mathrm{C}$ ) baru kemudian ditambahkan stater yogurt. Diinkubasi selama 8 jam. Yogurt yang sudah terbentuk ditambahkan maltodekstrin sesuai perlakuan dan dikeringkan kemudian dianalisa. Parameter pengamatan dilakukan berdasarkan analisa yang meliputi: kadar protein, total mikroba, total asam dan kadar air.

\section{Penentuan Kadar Protein}

Pengukuran kadar protein dilakukan dengan Metode Kjedahl (Nasution, 2006). Sebanyak $2 \mathrm{~g}$ sampel dimasukkan kedalam labu kjedahl, ditambahkan 0,5 g selenium, dan $25 \mathrm{ml} \mathrm{H}_{2} \mathrm{SO}_{4}$ didestruksi selama lebih kurang 2 jam sampai terbentuk larutan hijau kekuning-kuningan lalu didinginkan. Diukur volume hasil destruksi diencerkan dalam labu takar $250 \mathrm{ml}$ sampai garis tanda. Sebanyak 100 ml yang telah diencerkan, dimasukkan kedalam labu destilasi dengan $30 \mathrm{ml} \mathrm{NaOH} \mathrm{30 \%} \mathrm{selama} 1$ jam, destilatnya ditampung dengan beakergelas berisi $25 \mathrm{ml} \mathrm{H}_{3} \mathrm{BO} 33 \%$ telah ditetesi dengan indicator tashiro sebanyak 2 tetes hingga berwarna ungu/violet. Destilat sudah tidak bereaksi lalu diukur volume destilat. Diambil $5 \mathrm{ml}$ destilat dan dititrasi $\mathrm{HCl} 0,1 \mathrm{~N}$ terbentuk warna ungu muda. 


\section{Penentuan Total Mikroba}

Pengukuran total mikroba dilakukan dengan Metoda Total Plate Count (Fardiaz, 1992). Bahan diambil sebanyak $1 \mathrm{ml}$ dan dimasukkan kedalam tabung reaksi kemudian ditambahkan aquadest $9 \mathrm{ml}$ dan diaduk sampai merata. Hasil pengenceran ini diambil dengan pipet volume sebanyak $0,1 \mathrm{ml}$ kemudian ditambahkan aquadest $9,9 \mathrm{ml}$. Pengenceran ini dilakukan sampai $10^{8}$. Dari hasil pengenceran pada tabung reaksi yang terakhir diambil sebanyak $1 \mathrm{ml}$ dan diratakan pada medium agar PCA yang telah disiapkan di atas cawan petridish, selanjutnya diinkubasi selama 24 jam pada suhu $32^{\circ} \mathrm{C}$ dengan posisi terbalik. Jumlah koloni yang ada dihitung dengan colony counter dengan persamaan 1:

Total koloni $=\frac{1}{\text { Faktor Pengencer }}$

\section{Penentuan Total Asam}

Pengukuran total asam dilakukan menurut Fox, (1981) dengan cara ditimbang contoh sebanyak 18 gram, dimasukkan kedalam labu ukur dan ditambahkan aquadest sampai volume $100 \mathrm{ml}$. Dihomogenkan dan diambil filtratnya sebanyak $10 \mathrm{ml}$ dan dimasukkan kedalam Erlenmeyer lalu ditambahkan phenolpthalen $1 \%$ sebanyak 2-3 tetes kemudian dititrasi dengan menggunakan $\mathrm{NaOH}$ $0,1 \mathrm{~N}$. Titrasi dihentikan setelah timbul warna merah jambu yang stabil. Kadar asam laktat dapat dihitung menggunakan persamaan 2 :

Total asam $(\%)=\frac{\mathrm{ml} \mathrm{NaOH} \times 0,09 \times \text { faktor pengencer }}{\text { Berat awal }} \times 100 \%$

\section{Penentuan Kadar Air}

Pengukuran kadar air dilakukan menurut Sudarmadji et al., (1996) dengan cara ditimbang sampel sebanyak 3-5 gram lalu dimasukkan kedalam cawan yang terlebih dahulu telah ditimbang dan dikeringkan. Kemudian masukan kedalam oven padasuhu $105^{\circ} \mathrm{C}$ selama 2 jam. Dinginkan dalam desikator kemudian timbang dan penghitungan kadar air menggunakan persamaan 3:

Kadar air $(\%)=\frac{\text { Berat basah }- \text { Berat kering }}{\text { Berat basah }} \times 100 \%$

\section{HASIL DAN PEMBAHASAN}

\section{A. Kadar Protein (\%)}

Maltrodekstrin signifikan meningkatkan kadar protein pada yoghurt bubuk biji nangka (Gambar 1). Diperoleh hubungan linier positif antara konsentrasi maltodekstrin terhadap kadar protein pada yoghurt bubuk biji nangka dengan persamaan regresi $\mathrm{Y}=0,1233 \mathrm{M}+1,5073$ dan nilai koefisien regresi sebesar 0,8015 (tergolong sangat kuat). Artinya semakin tinggi penambahan konsentrasi maltodekstrin sampai $25 \%$ maka kadar protein pada yoghurt bubuk biji nangka semakin meningkat. Penambahan maltodekstrin sebagai penstabil agar produk yoghurt mempunyai konsistensi dan stabilitas yang baik, jadi semakin konsistensinya tinggi semakin tinggi protein yang terdapat pada produk. Hal ini disebabkan maltodekstrin memiliki sifat mudah larut dalam air dan meningkatkan total padatan terlarut seperti kadar protein pada yogurt bubuk. Hal ini mengakibatkan kadar protein semakin meningkat.

Hal ini sesuai dengan penelitian Wuryantoro dan Susanto, (2014) menyatakan bahwa maltodekstrin bersifat surfaktan (pembasah) dan mudah larut dalam air, serta membantu mempercepat penetrasi cairan ke dalam yogurt bubuk. Purba et al., (2012) menyatakan bahwa penambahan maltodekstrin dapat meningkatkan total padatan terlarut (TPT) seperti oligosakarida, protein, dan lemak pada yogurt bubuk. TPT ini akan didegradasi menjadi senyawa-senyawa lebih sederhana dengan berat molekulnya lebih rendah dari sebelumnya sehingga akan mempercepat waktu larut yogurt bubuk. Yuliawaty dan Susanto, (2015) melaporkan bahwa penambahan maltodekstrin dapat meningkatkan rendemen pada soyghurt bubuk dikarenakan maltodekstrin dapat meningkatakn jumlah total padatan, sehingga semakin banyak maltodekstrin yang ditambahkan maka semakin meningkat 
jumlah rendemen pada soyghurt bubuk. Triyono, (2010) juga melaporkan bahwa penambahan maltodekstrin yang semakin tinggi sampai $25 \%$ akan mengikat protein semakin tinggi.

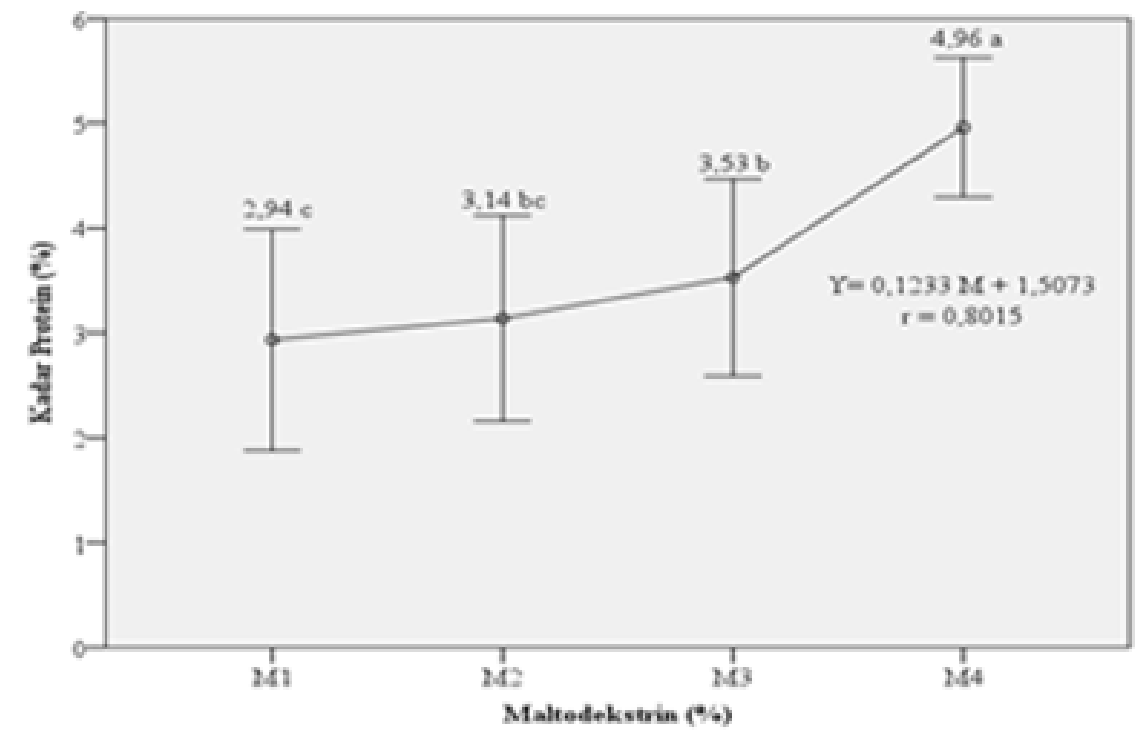

Gambar 1. Hubungan Pengaruh Penambahan Maltodekstrin terhadap Kadar Protein pada Yoghurt bubuk biji nangka.

\section{B. Total Mikroba (CFU/g)}

Pengaruh maltrodekstrin terhadap total mikroba dapat dilihat pada Gambar 2. Diperoleh hubungan linier positif antara konsentrasi maltodekstrin terhadap total mikroba pada yoghurt bubuk biji nangka dengan persamaan regresi $\mathrm{Y}=0,0195 \mathrm{M}+8,4698$ dan nilai koefisien regresi sebesar 0,9576 (tergolong sangat kuat). Artinya semakin tinggi penambahan konsentrasi maltodekstrin sampai $25 \%$ maka total mikroba pada yoghurt bubuk biji nangka semakin meningkat.

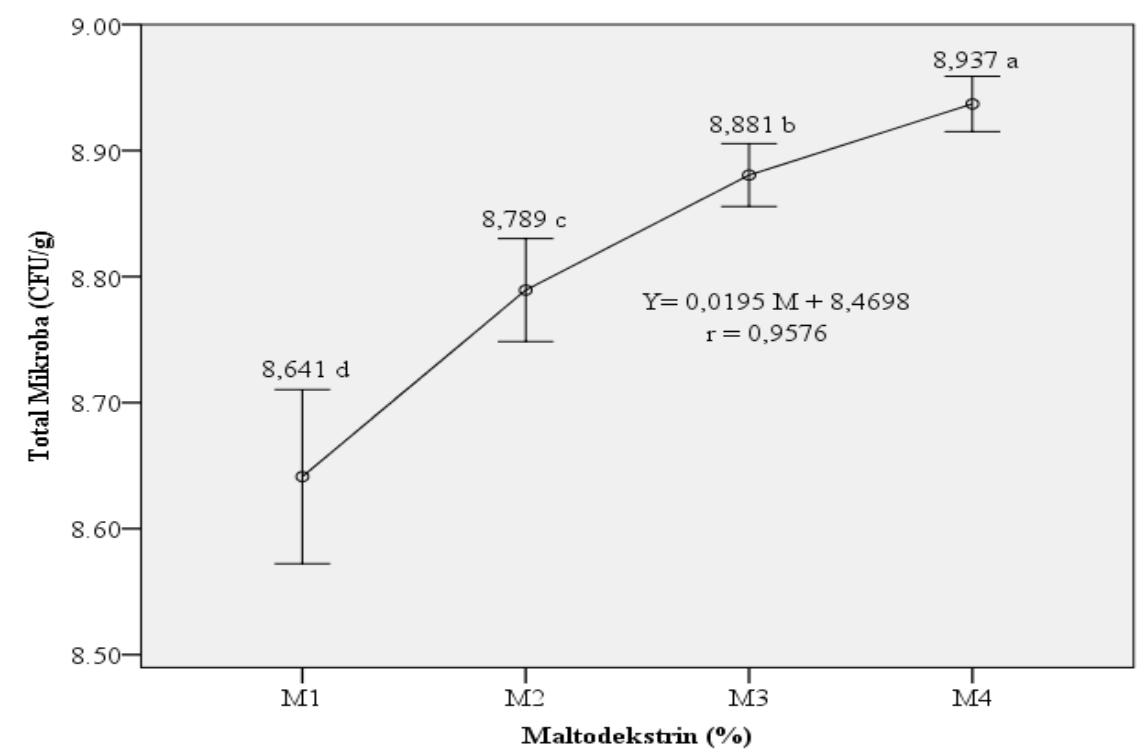

Gambar 2. Hubungan Pengaruh Penambahan Maltodekstrın terhadap lotal Mıkroba pada Yoghurt Bubuk Biji Nangka

Semakin tinggi penambahan maltodekstrin maka total mikroba akan meningkat. Hal ini disebabkan suhu yang digunakan saat menambahkan stater yogurt berkisar $40-44^{\circ} \mathrm{C}$ dan kisaran suhu ini tersebut mendukung pertumbuhan optimum miktoba khususnya bakteri asam laktat. Selain itu, sifat maltodekstrin dapat berfungsi sebagai bahan tambahan pangan yang dapat melindungi bahan dari kerusakan. Hal ini sesuai dengan penelitian Teixeira (2014) melaporkan bahwa starter bakteri 
Lactobacillus bulgaricus memiliki suhu optimum untuk mendukung pertumbuhan berkisar $40-50^{\circ} \mathrm{C}$ dan maksimum sampai $62^{\circ}$ C. Lamont et al., (2017); Sauer et al., (2017) melaporkan bahwa bakteri asam laktat merupakan bakteri gram positif anaerob fakultatif yang dilaporkan terdapat pada makanan kaya nutrisi dan bergantung pada asam amino dan karbohidrat yang difermentasi menjadi asam organik, sehingga mempengaruhi tingkat penggandaan. Sugindro et al., (2008) menunjukkan bahwa semakin tinggi konsentrasi penyalut, efisiensi enkapsulasi semakin meningkat, lapisan kulit (shell) semakin baik dan kuat,sehingga dapat melindungi bahan inti dengan baik serta melindungi zat yang mudah menguap ketika proses pengeringan berlangsung, yang berakibat retensi bahan inti akan semakin meningkat. Penyalut yang terlalu tinggi juga menyebabkan pembengkakan (puffing) atau penggelembungan (balloning) dan keretakan partikel yang akan menurunkan retensi bahan inti. Perlakuan dengan penambahan konsentrasi maltodekstrin 25\% dapat mempertahankan viabilitas sel yang lebih baik dibandingkan dengan perlakuan lainnya. Chávarri et al., (2012) melaporkan bahwa penambahan maltodekstrin dapat meningkatkan viabilitas bakteri pada pengeringan beku dan menstabilkannya selama penyimpanan. Lailiyah dan Indrawati, (2014) juga melaporkan bahwa penambahan jumlah maltodekstrin 15\% dengan lama pengeringan 14 jam menghasilkan jumlah koloni bakteri asam laktat tertinggi $\left(3,3 \times 10^{5} \mathrm{koloni} / \mathrm{gram}\right)$ dibandingkan perlakuan lainnya.

\section{Total Asam (\%)}

Pengaruh maltrodekstrin terhadap total asam dapat dilihat pada Gambar 3. Diperoleh hubungan linier negatif antara konsentrasi maltodekstrin terhadap total asam pada yoghurt bubuk biji nangka dengan persamaan regresi $\mathrm{Y}=-0,1736 \mathrm{M}+6,0594$ dan nilai koefisien regresi sebesar 0,9923 (tergolong sangat kuat). Artinya semakin tinggi penambahan konsentrasi maltodekstrin sampai $25 \%$ maka total asam pada yoghurt bubuk biji nangka semakin berkurang

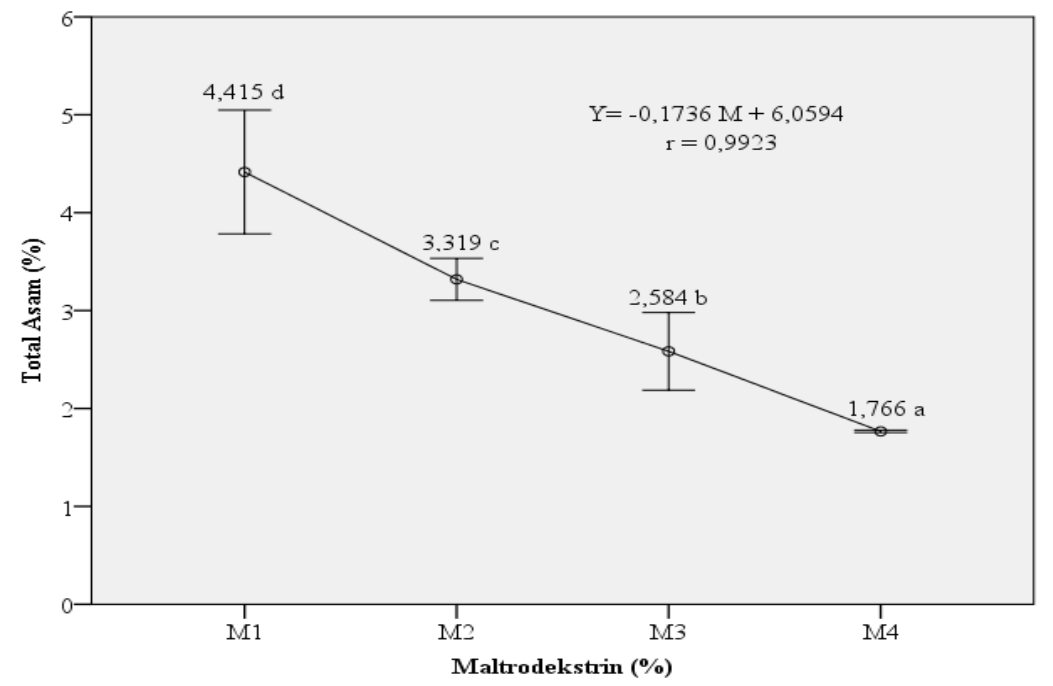

Gambar 3. Hubungan Pengaruh Penambahan Maltodekstrin terhadap Total Asam pada Yoghurt Bubuk Biji Nangka.

Semakin tinggi penambahan maltodekstrin sampai $25 \%$ maka kandungan total asam pada yoghurt bubuk biji nangka semakin berkurang. Hal ini disebabkan total mikroba yang terdapat pada yoghurt bubuk biji nangka semakin meningkat seiring dengan peningkatan konsentrasi maltodekstrin sampai 25\% (Gambar 2) sehingga hasil fermentasi bakteri asam laktat seperti asam laktat, asam asetat, dan asam lainnya mudah menguap. Hal ini sesuai dengan penelitian Purwati et al., (2008) menyatakan bahwa semakin banyak penambahan maltodekstrin, total asam tertitrasi yogurt bubuk hasil rehidrasi yang dihasilkan semakin rendah. Total asam tertitrasi yogurt bubuk menunjukkan hubungan yang berbanding terbalik dengan $\mathrm{pH}$. Djali et al., (2016) melaporkan bahwa penambahan maltodekstrin dari 5-30\% signifikan terhadap penurunan total asam tertitrasi sampai $0,31 \%$ dari yoghurt bubuk kacang roro pedang. Djali et al., (2017) melaporkan bahwa penambahan konsentrasi maltodekstrin dari sampai $30 \%$ signifikan menurunkan total asam tertitrasi sampai $0,56 \%$ dari soygurt bubuk kacang kedelai. 


\section{Kadar Air (\%)}

Pengaruh maltrodekstrin terhadap kadar air dapat dilihat pada Gambar 4. Diperoleh hubungan linier positif antara konsentrasi maltodekstrin terhadap kadar air pada yoghurt bubuk biji nangka dengan persamaan regresi $\mathrm{Y}=0,0141 \mathrm{M}+2,7668$ dan nilai koefisien regresi sebesar 0,961 (tergolong sangat kuat). Artinya semakin tinggi penambahan konsentrasi maltodekstrin sampai 25\% maka kadar air pada yoghurt bubuk biji nangka semakin meningkat. Hal ini disebabkan karena sifat maltodekstrin yang memiliki higroskopis yang rendah sehingga dapat mengikat kandungan air dalam bahan.

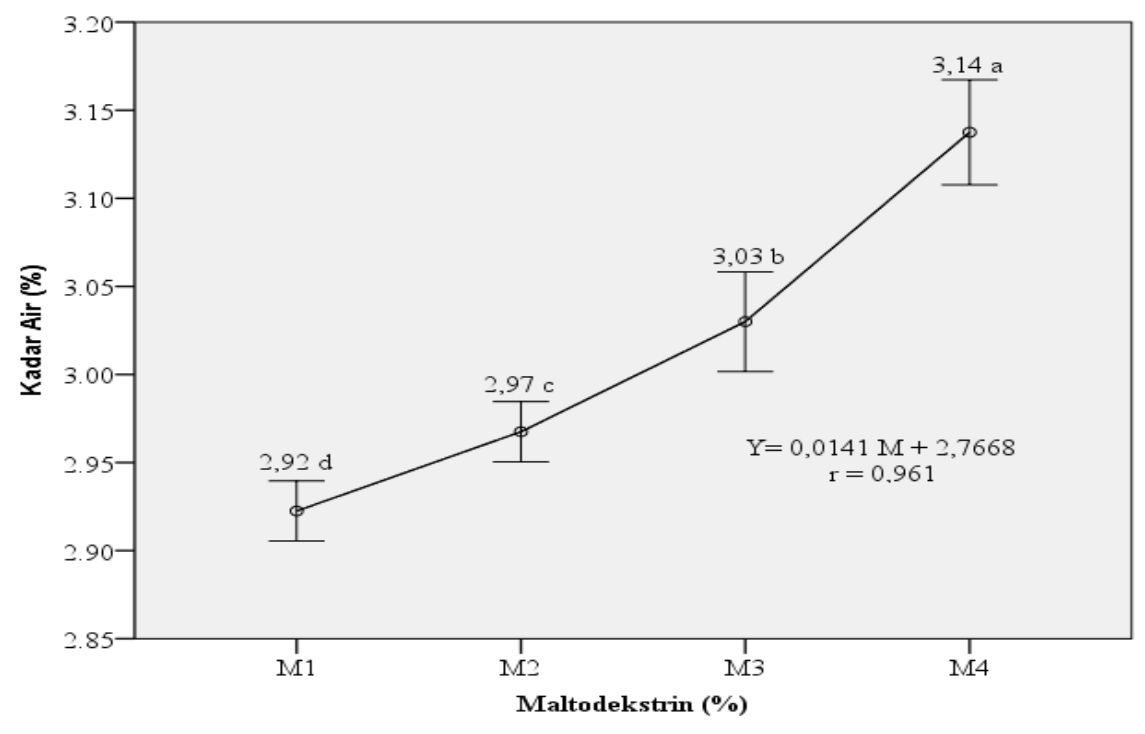

Gambar 4. Hubungan Pengaruh Penambahan Maltodekstrin terhadap Kadar Air pada Yoghurt Bubuk Biji Nangka

Hal ini sesuai dengan penelitian Hui, (1993) menyatakan bahwa molekul maltodekstrin mempunyai banyak gugus hidroksil sehingga dapat mengikat air dalam jumlah besar. Terjadinya ikatan antara gugus hidroksil dengan molekul air akan menyebabkan molekul air yang semula berada di luar granula maltodekstrin dan dalam keadaan bebas menjadi berada dalam granula dan tidak bebas lagi. Semakin tinggi kadar maltodekstrin yang ditambahkan semakin kental suspensi yang dihasilkan sehingga semakin sulit terjadinya penguapan air, karena maltodekstrin mempunyai kemampuan pengikatan yang baik. Husniati, (2009) melaporkan bahwa maltodekstrin memiliki sifat daya larut yang tinggi, mengalami dispersi yang cepat, higroskopis yang rendah, browning yang rendah, dan menghambat kristalisasi. Yana dan Kusnadi, (2015) melaporkan bahwa penambahan konsentrasi maltodekstrin yang tinggi menghasilkan produk dengan rendemen yang tinggi tetapi memiliki kadar air yang rendah.

\section{KESIMPULAN}

Penambahan konsentrasi maltodekstrin dari 10-25\% menunjukkan peningkatan kadar protein, total mikroba, dan kadar air, namun menurunkan total asam pada yoghurt bubuk biji nangka. Konsentrasi maltodekstrin $25 \%$ menunjukkan perlakuan terbaik terhadap kadar protein, total mikroba, kadar air, dan total asam dibandingkan konsentrasi lainnya.

\section{UCAPAN TERIMA KASIH}

Penulis mengucapkan terima kasih kepada Lembaga Penelitian dan Pengabdian Masyarakat (LP2M) Universitas Muhammadiyah Sumatera Utara melalui Skim Penelitian Terapan yang telah mendanai penelitian ini dengan nomor 121/II.3-AU/UMSU-LP2M/C/2020. 


\section{DAFTAR PUSTAKA}

Askar, S., \& Sugiarto. (2005). Uji kimiawi dan organoleptik sebagai uji mutu yoghurt. Prosiding Temu Teknis Nasional Tenaga Fungsional Pertanian, Bogor.

Azizah, N., Pramono, Y. B., \& Abduh, S. B. M. (2013). Sifat fisik, organoleptik, dan kesukaan yogurt drink dengan penambahan ekstrak buah nangka. Jurnal Aplikasi Teknologi Pangan, 2(3), 148151.

Badarudin, T. (2006). Penggunaan maltodekstrin pada yoghurt bubuk ditinjau dari uji kadar air keasamam, $\mathrm{pH}$, rendemen, reabsorpsi uap air, kemampuan keterbasahan, dan sifat kedispersian. Skripsi. Universitas Brawijaya, Malang.

Chávarri, M., Marañón, I., \& Villarán, M. C. (2012). Encapsulation technology to protect probiotic bacteria. In Probiotics. IntechOpen. doi:10.5772/50046.

Djali, M., Indiarto, R., \& Avila, V. (2017). Evaluasi penggunaan maltodekstrin pada pembuatan soyghurt bubuk dengan metode pengeringan beku. Jurnal Penelitian Pangan, 2(1), 9-17.

Djali, M., Marta, H., \& Harnah, S. (2016). Characterics of freeze dried jack bean yogurt powder with maltodextrin as coating material. Jurnal Penelitian Pascapanen Pertanian, 13(1), 28-35. doi:10.21082/jpasca.v13n1.2016.28-35.

Estiasih, T., \& Sofia, E. (2009). Stabilitas antioksidan bubuk keluwak (Pangium edule Reinw) selama pengeringan dan pemasakan. Jurnal Teknologi Pertanian, 10(2), 115-122.

Fardiaz, S. (1992). Mikrobiologi pangan. Dirjen Pendidikan Tinggi, Dekdikbud, PAU Institut Pertanian Bogor.

Fox, J. D. (1981). Food analysis a laboratory manual. Department of Animal Science, University of Kentucky, Kentucky.

Guntiawati, I. (2007). Pengaruh konsentrasi starter tehadap kualitas yoghurt susu kambing. Tesis. Universitas Muhammadiyah Malang.

Historiya, A. (2017). Kualitas minuman serbuk instan buah pakel (Mangifera foetida Lour) dengan variasi konsentrasi maltodekstrin. Skripsi. Universitas Atma Jaya, Yogyakarta.

Hoppert, K., Zahn, S., Jänecke, L., Mai, R., Hoffmann, S., \& Rohm, H. (2013). Consumer acceptance of regular and reduced-sugar yogurt enriched with different types of dietary fiber. International Dairy Journal, 28(1), 1-7. doi:10.1016/j.idairyj.2012.08.005.

Hui, Y. H. (1993). Dairy science and technology handbook. VCH Publisher, Inc., New York

Husniati, H. (2009). Studi karakterisasi sifat fungsi maltodekstrin dari pati singkong. Indonesian Journal of Industrial Research, 3(2), 133-138.

Lailiyah, N., \& Indrawati, V. (2014). Pengaruh jumlah maltodekstrin dan lama pengeringan terhadap sifat organoleptik yoghurt susu kedelai bubuk. Jurnal Online Tata Boga, 3(1), 65-78.

Lamont, J. R., Wilkins, O., Bywater-Ekegärd, M., \& Smith, D. L. (2017). From yogurt to yield: Potential applications of lactic acid bacteria in plant production. Soil Biology and Biochemistry, 111, 1-9. doi:10.1016/j.soilbio.2017.03.015.

MD, M., \& Surnaherman. (2018). Pemanfaatan biji nangka sebagai bahan alternatif pembuatan yogurt instan. Agrium: Jurnal Ilmu Pertanian, 21(2), 166-172. doi:10.30596/agrium.v21i2.1876.

MD, M., Syakir, N. S., \& Joko, P. (2016). Pemanfaatan biji nangka sebagai bahan pembuatan yogurt. Penelitian Jurusan Ilmu Teknologi Pangan, Universitas Muhammadiyah Sumatera Utara. Medan.

Nasution, E. Z. (2006). Studi pembuatan pakan ikan dari campuran ampas tahu, ampas ikan, darah sapi potong, dan daun keladi yang disesuaikan dengan standar mutu pakan ikan. Jurnal Sains Kimia, 10(1), 40-45.

Nurhidayat. (2009). Fermentasi dan mikroorganisme yang terlibat. (Online). Diakses dari: http://nurhidayat.lecture.ub.ac.id/page/23/

Purba, R. A., Rusmarilin, H., \& Nurminah, M. (2012). Studi pembuatan yoghurt bengkuang instan dengan berbagai konsentrasi susu bubuk dan starter. Jurnal Rekayasa Pangan dan Pertanian, $1(1), 6-15$.

Purwati, H., Istiawaty, H., Aylianawati., \& Soetaredjo, F. E. (2008). Pengaruh waktu simpan terhadap kualitas soyghurt dengan penambahan susu bubuk. Widya Teknik, 7(2), 134-143. doi:10.33508/wt.v7i2.1268. 
Sauer, M., Russmayer, H., Grabherr, R., Peterbauer, C. K., \& Marx, H. (2017). The efficient clade: lactic acid bacteria for industrial chemical production. Trends in biotechnology, 35(8), 756-769. doi:10.1016/j.tibtech.2017.05.002.

Sudarmadji, S., Haryona, B., \& Suhardi. (1996). Prosedur analisa untuk bahan makanan dan pertanian. Liberty, Yogyakarta.

Sugindro., Mardliyati, E., \& Djajadisastra, J. (2008). Pembuatan dan mikroenkapsulasi ekstrak etanol biji jinten hitam pahit (Nigella sativa Linn.). Pharmaceutical Sciences and Research (PSR), 5(2), 57-66. doi:10.7454/psr.v5i2.3419.

Teixeira, P. (2014). LACTOBACILLUS | Lactobacillus delbrueckii ssp. bulgaricus. Encyclopedia of food microbiology, 2nd ed. Jamestown Road, London. doi:10.1016/B978-0-12-384730$0.00177-4$.

Triyono, A. (2010). Mempelajari pengaruh maltodekstrin dan susu skim terhadap karakteristik yoghurt kacang hijau (Phaseolus radiatus L.). Seminar Rekayasa Kimia dan Proses, 4-5 Agustus 2010.

Wuryantoro, H., \& Susanto, W. H. (2014). Penyusunan standard operating procedures industri rumah tangga pangan pemanis alami instan sari stevia (Stevia rebaudiana). Jurnal Pangan dan Agroindustri, 2(3), 76-87.

Yana, M. F., \& Kusnadi, J. (2015). Pembuatan yogurt berbasis kacang tunggak (vigna unguiculata) dengan metode freeze drying (kajian jenis dan konsentrasi bahan pengisi). Jurnal Pangan dan Agroindustri, 3(3), 1203-1213.

Yuliwaty, S. T., \& Susanto, W. H. (2015). Pengaruh lama pengeringan dan konsentrasi maltodekstrin terhadap karakteristik fisik kimia dan organoleptik minuman instan daun mengkudu (Morinda citrifolia L). Jurnal Pangan dan Agroindustri, 3(1), 41-52. 